\title{
Research on Challenges and Countermeasures of College Students' Ideological Education in the New Period
}

\author{
Li Chiping \\ Hua Li College, Guangdong University of Technology \\ Guangzhou, Guangdong, China 511325
}

\begin{abstract}
With the arrival of the era of knowledge economy, the development of China's higher education has entered a new phase, the scale of university education has expanded rapidly, and the management system reform has gradually deepened. Under the new situation, the ideological education work in colleges and universities meets some challenges. How to adapt to the new situation and find new countermeasures has become an important issue that needs to be resolved in the ideological and political work of colleges and universities.
\end{abstract}

Keywords-Challenges, Countermeasures; College Students; Ideological Education; New Period

\section{INTRODUCTION}

In recent years, China's socialist construction has developed rapidly, and higher education reform has begun to expand in an all-round way. Higher education has entered a new historical period. Colleges and universities have moved from the margins of society to the center of society and are responsible for talent cultivation. Study and serve the historical mission of society. How colleges and universities adapt to new challenges posed by the ideological and political work of students in the new era is a question that major universities need to seriously consider. This paper analyzes the major challenges faced by college students in the new era, and puts forward some targeted countermeasures and suggestions.

\section{The ConNotation And Status OF COLlEGE STUdent WORK IN THE NEW ERA.}

The content of college students' work is very complex, and generally includes: daily management and services, student ideological education, recruitment and employment, and campus cultural activities. In the past, the work of students in colleges and universities has always been based on class as the basic unit. The main content of the work is student class management and ideological and political education, and indoctrination education, while class management emphasizes the leadership of class teacher and counselor. However, with the continuous deepening of higher education reform, this traditional student ideological education work model is increasingly difficult to solve new problems in the new era. Therefore, in the new period, we must update the ideological education work model for college students according to the actual situation.

Contemporary college students are ideologically active, easy to accept new things, and pay attention to personality cultivation. Only by accurately grasping the personality characteristics and psychological needs of college students can we find suitable education methods to guide education, so as to truly improve students' ideological and political qualities.

According to the connotation of college student work in the new era, we know that college students' ideological education plays an extremely important role in the management of college students. Only when students' ideological education is done well can student management work be carried out smoothly. Therefore, we should pay attention to the development needs of students as the fundamental starting point for students' ideological education work, and effectively protect the legitimate rights and interests of each student. According to the different personality characteristics and psychological needs presented by each student, each individual should be well-different and teach students in accordance with their aptitude. Otherwise, it will directly affect the moral formation of the cultivated talents, and it cannot provide a good learning and living environment for students. The ideological education of college students can only organically combine care and respect with education and management, and fully mobilize the subjective initiative of students in management so as to give full play to the role of undergraduate ideological and political education in student management.

\section{The Challenges FACED By COLLEGE STUDENTS IN THE NEW ERA}

With the gradual establishment of market economy system, continuous deepening of reform policies, and increasing openness to the outside world, the rapid development of modern science and technology has penetrated information network technology into all aspects of social life. The reform of the enrollment system and the expansion of the enrollment scale the implementation of the credit system and minors have brought great challenges and challenges to the ideological education of college students. The following will be a specific analysis: 


\section{A. Challenges of Economic Globalization.}

Economic globalization is the main trend of world economic development in the $21 \mathrm{st}$ century under the leadership of Western developed countries. For developing countries, it is a "double-edged sword" that not only promotes the rapid economic development of developing countries, but also poses a severe challenge to the overall reform of developing countries. The addition of the WTO means that China has already incorporated the trend of economic globalization, and all-round and multi-level foreign exchanges and cooperation will be more frequent. When a large number of funds, technologies, management, and talents are introduced, the trends of thoughts, values, and lifestyles of Western societies will follow suit. The methods of "westernization" and "differentiation" will be even more powerful and more vigorous. Against this background, the decadent ideology of the western bourgeoisie and the negative impact of the market economy have all impacted college students' world outlook, outlook on life and values. Therefore, the ideological education of college students should focus on how to make students have both international awareness and strong national self-esteem and pride. While learning and inheriting the fine cultural traditions of the Chinese nation, we must also absorb the excellent culture of all countries in the world. Focus on cultivating their ability to consciously resist "westernization" and "differentiation."

\section{B. Challenges of Market Economy}

With the initial establishment and gradual improvement of the socialist market economic system, contemporary college students have grown up during the process of reform and opening up and the establishment of a market economic system. A special growth environment must inevitably be deeply imprinted in its ideological consciousness. In the new era, the market economy is playing a more and more important role. The openness and diversification of this social environment has made contemporary college students more complex and diverse in thinking, leading to marked differences in ideological awareness, level of understanding, and ideological concepts among students. Contemporary college students are faced with multiple values, economic environment and social trends. They will inevitably produce a diversified outlook on life, values, and the world. Their thinking presents multiple contradictions, which are manifested as focusing on material enjoyment, focusing on self-fulfillment, emphasizing the development of individuality, ignoring spiritual pursuits, ignoring dedication, and ignoring group spirit. Against this background, we must seriously study and improve the hard and soft environments of higher education institutions from the perspective of educating people and pay attention to creating a good academic environment, a teacher-degraded environment, and a management environment. Focusing on upholding socialist ethics, we must use a scientific attitude to effectively strengthen the social practice education of college students and arouse the social responsibility of college students. This is an important task for the ideological and political work of college students.

\section{Challenges of Science and Technology.}

With the rapid development of science and technology, science and technology have greatly promoted socio-economic development, and information network technology has penetrated into all aspects of social life, providing tremendous convenience for the people's material and spiritual life. But it also brought many new ethical issues. In this environment, traditional methods of education and education are under attack. Therefore, we should pay attention to cultivating students to master modern scientific and technological knowledge while also having a high degree of social ethical responsibility and self-discipline.

Challenges of Diversification of Information Sources. With the rapid development of information technology, information network technology has penetrated into all aspects of social life. With its unique charm, rich and varied network culture has attracted more and more college students, more extensive information sources, more complex information contents, and dissemination. The speed is faster and more convenient. People are soberly aware that the information network is indeed a double-edged sword, and its negative effects must not be ignored. Under such circumstances, it is important to enable young students to have the ability to obtain information and seek truth, and to have the ability to independently screen and identify information. It is an important task of ideological and political work to be able to use the Internet and avoid disadvantages.

\section{NEW CHANGES IN THE IDEOLOGICAL AND POLITICAL WORK ENVIRONMENT FOR COLLEGE STUDENTS}

With the development of higher education and the deepening of the reform of the management system within the school, the environment for the ideological and political work of college students has also undergone great changes. The major changes are:

With the gradual establishment of the socialist market economic system, the reform of the management system within the school is also developing vertically.Including the reform of the establishment of management institutions within the school, strengthen the preparation of management, reduce non-teaching staff, deepen the reform of the employment system and deepen the reform of the school distribution system and other aspects. As the current scale of higher education expands year by year, and the number of undergraduate students increases drastically, the original student work mechanism is difficult to adapt to the trend of higher education reform in the new era. Teachers and students have deeply felt the role of the market economy. This urgently requires the establishment of a campus atmosphere that is compatible with the market economy and cultivates students' moral values.

The current colleges and universities generally implement a three-level management system for secondary schools or colleges. With the decentralization of management power in the school and the decentralization of the center, with the adjustment of the internal layout of universities, many schools have shown the trend of running schools on multiple campuses School-level management is more emphasis on grass-roots 
services and teaching services. With the expansion of the enrollment scale and the deepening of teaching reforms, new teaching models such as "hierarchical teaching", "curriculum selection" and "credit system" have been universally implemented, resulting in the situation of "different classes in the same class and different classmates". The scope of interaction has expanded from the original fixed class to the entire campus. Therefore, we should focus on cultivating students to deal with the relationship between individual students and unstructured groups.

In the socialized reform of college logistics, many colleges and universities have used market mechanisms to build student apartments, which has greatly improved student accommodation conditions, which is conducive to expanding the scale of school running and improving the efficiency of school running. However, when college students enter students' apartments, they enter the community where the accommodation services are provided. The student accommodation is not restricted by grades, majors, classes, or even schools. There is a new situation of "different classes living in the same class and living in different classes". This is an urgent requirement. The ideological and political work of students can be extended to new areas to help students improve their ideological awareness.

The campus network project construction has been very popular. The network has covered college students' various places and provided convenience for students' study, life, and activities. The Internet has become an important part of college students' learning and living. While using the Internet for leisure and entertainment, it can also help college students get a variety of information. However, the large amount of information on the Internet, the content is uneven, and the speed of transmission is fast. This poses a severe challenge to the ideology and morals of undergraduates who are not deeply involved, and requires us to intervene.

\section{New Characteristics OF COLLEGE StUdENTS' THOUGHTS}

It should be said that the current overall state of mind of university students is good. They are wise and studious, forge ahead, have keen ideology, and have a heart for the motherland, are determined to become successful, and serve the society. However, there are also some students who have thoughts that are worthy of their own merit and show some new features. They are "centered on self-development." Nowadays, undergraduate entrance exams, practical knowledge, research crazes, and over-grade fevers have risen quietly. Many colleges have seen phenomena such as high rates of late self-study, tight seats in libraries, various practical knowledge training classes, and postgraduate counseling classes. However, in-depth analysis shows that some of the students' motivated motivations have little connection with national rejuvenation and social development, mainly because self-worth and self-struggle are at work.

Some students neglect their own overall development in the process of self-development and struggle. They only emphasize the accumulation of knowledge and the improvement of their abilities. They disregard the cultivation of good moral character and personality. It seems that knowledge and ability in the market economy are the "hard indicators" of competition. Ideals and morality are all empty talk. "This phenomenon of re-emphasizing light and morality has caused a strong contrast among some college students who are "highly educated, low-educated, knowledgeable, and uncultured".

College students should adopt more specific standards of interest when observing problems, dealing with problems, and judging right and wrong. As long as something is beneficial to itself or to the small group in which it belongs, it does not use global, objective, and fair standards. We should adopt more market economy standards than to adopt traditional moral standards. For many things, we adopt the attitude that "If we are profitable, we are good at doing something, we are good at doing something but we are not good at it", we think that giving dedication and being a group are "fools". We should adopt a more critical attitude rather than adopt a constructive attitude. Some students take extreme negative attitudes toward people or things that they dislike, and they accuse others and criticize others. They rarely take the "transitional thinking" approach objectively and dialectically, and propose some constructive issues.

\section{COUNTERMEASURES TO STRENGTHEN AND IMPROVE STUDENT WORK IN COLLEGES AND UNIVERSITIES IN THE NEW PERIOD}

Emancipate the mind, update the concept. Traditional ideological and political education takes simple preaching and indoctrination as the main forms. However, in the new historical period, we have shown new characteristics of the times. We cannot use the old model to meet new challenges, and we must change the traditional concept and model of exam-oriented education. We should innovate the idea of education to improve students' ideological education. The gradual deepening of the reform of the teaching system in colleges and universities and the arrival of the Internet information age have enabled today's college students to live in an open and pluralistic social environment. Social phenomena and ideological concepts have influenced all aspects of their growth. Single, school-only students Work is far from regulating the thinking and behavior of college students. To make college students' ideological and political work more appealing, attractive, and effective, we must increase their pertinence, focus on social hot spots and student needs, and make full use of the modern information delivery platform represented by the Internet. Political education goes online. The work of college students in the new era must be developed in an all-round and open-ended model. With campus culture as the medium, we must carry out activities that are content-rich, diverse, and entertaining, so that ideological and political education can infiltrate all aspects of student life; The focus of apartments is to expand the internal extension and extension of student work, and to form a "fulltime education" structure in which the whole school's departments and even students' families and the whole society participate. Combine the advantages of all parties organically to create a strong educational synergy, while doing a good job of ideological and political education with units as the unit, let 
the ideological and political work into the student community, form a criss-cross all-weather three-dimensional work network and pattern to provide strong protection for qualified personnel with solid political knowledge and solid basic knowledge in the new era.

Establish a highly qualified and efficient student work force. Leaders at all levels of the school must attach great importance to the ideological and political work of students and the team building of students' ideological and political work. The student work force is the main force of student work in universities. This team building is the key to meeting the challenges and winning the challenges in the work of college students in the new era. We must increase the necessary investment in ideological and political work, address issues such as funding for activities, venues for events, staff treatment, grade titles, and increase the training of ideological and political workers. In particular, student staff members should strengthen the study of the Party's theories, policies, laws, and regulations, and strengthen quality training. For example, if students are familiar with network knowledge, they can technically eliminate bad web pages or the impact of some rumors on the BBS on students. It is also convenient to communicate with college students so as to guide them to correctly understand the information obtained from the Internet. Second, university student workers must also recognize and study the new requirements for talent cultivation in the era of socialist market economy and the rapid development of high technology. Colleges and universities should work hard to form a team of student ideological and political work that is instructed by the party and the organization, with the counselors as the backbone, student advisors, classroom teachers, student leaders, and student party members doing their duties. The responsibility for the ideological and political work of students must be fully implemented. Of course, the construction of university student work teams is inseparable from the educational administrative decision-making level and the leadership of colleges and universities attach great importance to student work. Only by paying attention to student work in terms of organization and policy can the workforce of university students be strengthened in the ongoing reform of higher education. In order to ensure the orientation of higher education personnel training in the new era, the party's education policy has been implemented.

While strengthening education and scientific management, we must pay attention to building and perfecting the service system that ensures the development of university talent. First, all courses in colleges and universities have ideological and political education functions. All teachers should take responsibility for ideological and political education. However, we should vigorously broaden the channels for education. We must shift from indoctrination to active guidance and guidance in the means and methods of education, so that students can enhance political ideological awareness in a subtle manner. Secondly, the core of scientific management is the institution building. In the new period, colleges and universities should establish and improve various rules and regulations as soon as possible, and must increase the propaganda and education for students so that they can be institutionalized from the moment they enter school. The self-education, self-management, and self-service of the Chinese societies also allow student workers to no longer simply play the role of "firefighters," thereby increasing student work efficiency. Third, in response to the challenges posed by the popularization of higher education in the work of students, it is a very effective measure to construct and improve various service systems that guarantee student success. It is also a trend in the development of student work in universities. For example, it is possible to actively provide services for students by establishing service centers for undergraduate employment guidance centers, undergraduates' psychological health education guidance centers, and university students' work aid education guidance centers. In addition, the functions of college student work in the new era should not exist alone. It is necessary to combine education, management, and service organically to form an all-dimensional and three-dimensional student work model.

The "law" here may include the rules and regulations of the school, but it mainly refers to the laws and regulations of the country. With the higher education entering the stage of popularization and the gradual implementation of reforms in college teaching systems and logistics socialization, the learning and living of college students tend to be communitybased and socialized, and the management of universities, especially student management, has truly introduced "rulebased management" as an inevitable choice. "Administering the school according to the law" requires us to strengthen legal education for college students and effectively improve their legal concept so that college students entering the society can consciously use the law to restrict their own words and deeds and protect their own interests. Facing the challenge of ideological and political work for students in the development of modern media technology and the information age, we must fully recognize "de". The power to adhere to moral education in the quality of education in the first place, open up new ways of moral education, strengthens the moral education of college students. On the other hand, "Virtue" in "Ruling by Virtues" should also include the construction of teachers' morality. The construction of teachers' morality is a prerequisite and an important guarantee for the good work of college students in the new era. If teachers fail to do their teaching and learning, they will not be able to play a moral role model, and will even bring negative influence to students. This will make any effort in student work fail. Therefore, we should regard "ruling the country by virtue of the school" as an important means in the management of universities, especially student management. Of course, both "ruling the university by law" and "ruling the country by virtue" we must both grasp, and both hands must be hard.

\section{CONCLUSION}

In summary, in the face of the challenges of social development and higher education reform for student work in colleges and universities, if we can seriously analyze, diligent in thinking, put forward corresponding countermeasures, and pay close attention to implementation, we can turn challenges into opportunities and open the new situation of college students' work in the innovation period. 


\section{REFERENCES}

[1] Li Fengzhu, Huo Changquan. The Challenges of College Students Ideological and Political Education and Their Countermeasures [J]. Journal of Liaoning Administration Institute, 2015, (1).

[2] Huang Feiyan. New exploration of college students' ideological and political work $[\mathrm{J}]$. Journal of Chongqing University of Science and Technology (Social Science Edition), 2007, (2).

[3] Guo X L. Creative thinking on the ideological and political education of college students in the new era $[\mathrm{J}]$. Journal of Anhui Agricultural University (Social Sciences Edition), 2007, (2).

[4] Zhao Zhiling, Gao Xiang, Wang Zhen. On the Innovation of Ideological and Political Work in Colleges and Universities in the New Era [J]. Science and Technology Information, 2008, (4). 